\title{
Implementasi Electronic Health Record (EHR) Pada Poli Rawat Jalan Di Rumah Sakit Umum Daerah Ratu Zalecha Martapura
}

\author{
The Implementation of Electronic Health Record (EHR) At the Outpatient Polyclinic in \\ Regional General Hospital of Ratu Zalecha Martapura \\ Nina Rahmadiliyani ${ }^{1 *}$, Putri $^{2}$, Rina Gunarti ${ }^{1}$ \\ ${ }^{1}$ STIKes Husada Borneo dan Alamat JI A. Yani km 30,5 no 4 Banjarbaru \\ ${ }^{2}$ Alumni STIKes Husada Borneo dan Alamat JI A. Yani km 30,5 no 4 Banjarbaru \\ *Korepondensi: ninaroshan.nr@gmail.com
}

\begin{abstract}
A system of Electronic Health Record (EHR) is an activity computerized the contents of the medical record and process related. Based on the preliminary studies in Hospital of Ratu Zalecha Martapura obtained that already some clinics that implement EHR systems and for some clinics will get their turn to apply the system. The purpose of this research was to identify the security system (security), clinical support (clinical support), and reports (report) on the system of the EHR. The method of this research uses descriptive research with qualitative analysis. Research instrument this is manual observation and interview guidelines. This research was conducted to 8 informant head installation medical record, IT officers, three doctors and three nurses. The results of research at in Hospital of Ratu Zalecha Martapura to be able to access the EHR user must use a username and password. Username and password are made according to their respective limits and authority. Clinical support in the system is good, doctors and nurses fill their own diagnoses into EHR applications, service time is more effective and more efficient so as to improve patient services. Reports produced were reports of 10 major outpatient diseases, outpatient visit reports, daily outpatient census reports, $R L 1, R L 2, R L 3, R L 4$ and $R L 5$.
\end{abstract}

Keywords : Electronic Health Record, security, clinical support

\section{Pendahuluan}

Undang-undang RI No 44 tahun 2009 Rumah Sakit adalah institusi pelayanan kesehatan bagi masyarakat dengan karakteristik tersendiri yang dipengaruhi oleh perkembangan ilmu pengetahuan kesehatan, kemajuan teknologi, dan kehidupan sosial ekonomi masyarakat yang harus tetap mampu meningkatkan pelayanan yang lebih bermutu dan terjangkau oleh masyarakat agar terwujud derajat kesehatan yang setinggi-tingginya, merupakan institusi pelayanan kesehatan yang menyelenggarakan pelayanan kesehatan perorangan secara paripurna yang menyediakan pelayanan rawat inap, rawat jalan, dan gawat darurat (1).

EHR merupakan rekaman atau catatan elektronik informasi terkait kesehatan (Health-Record-Information) yang mencakup informasi pasien seperti informasi kontak pribadi, riwayat medis pasien, alergi, hasil tes, dan rencana perawatan. Beberapa manfaat EHRs termasuk meningkatkan efisiensi, meningkatkan hasil positif pasien, dan kesehatan populasi (2).

Beberapa penelitian telah menemukan bahwa penggunaan EHR yang bermakna telah meningkatkan proses kualitas dan hasil klinis di beberapa rumah sakit, sebagian dengan menyediakan alat yang meningkatkan manajemen organisasi (Appari et al., 2013). Selain meningkatkan kualitas perawatan pasien, penggunaan EHR yang bermakna dapat menyebabkan keuntungan finansial bagi penyedia perawatan melalui penggunaan staf yang lebih efisien, dan manajemen informasi yang lebih efisien untuk penggantian pihak ketiga (3)

Menurut AHIMA dalam Journal of AHIMA 83 No.7 (2012), yaitu Data Quality Management Model (Updated), semakin lama system Electronic Health Record (EHR) menjadi lebih banyak diterapkan di semua pengaturan kesehatan. Sistem ini telah dikembangkan dan digunakan dengan 
berbagai metode dokumentasi sebagai salah satu catatan elektronik.Oleh karena itu, dibutuhan pengelolaan kualitas data, pelayanan, manajemen, dan pengukuran yang lebih ketat/besar dari sebelumnya. Selain itu, hal ini dapat menimbulkan perhatian untuk menjamin integritas data dalam pelaksanaan kegiatan, metode pengumpulan, atau sistem yang digunakan untuk merekam, menyimpan, dan mengirimkan data pada pelayanan kesehatan (4).

Electronic Health Record (EHR) belum banyak mengimplementasikan pada Rumah Sakit.. RSUD Ratu Zalecha Martapura merupakan Rumah Sakit di Kalimantan yang telah menerapkan EHR. Studi pendahuluan di RSUD Ratu Zalecha Martapura dengan wawancara langsung kepada Petugas IT di Instalasi Rekam Medis di RSUD Ratu Zalecha Martapura, peneliti memperoleh informasi bahwa RSUD Ratu Zalecha Martapura telah menggunakan sistem EHR di Poli Rawat Jalan kurang lebih tiga bulan terhitung sejak pertama kali dilaksanakan pelayanan yaitu pada bulan Januari 2018. Pada hasil wawancara didapatkan bahwa sudah beberapa poliklinik yang menerapkan sistem EHR dan untuk beberapa poliklinik akan mendapatkan giliran menerapkan sistem tersebut. Pada saat ini, RSUD Ratu Zalecha Martapura masih dalam tahap pengembangan EHR agar dapat sesuai dengan kebutuhan dan harapan rumah sakit. Dengan pengimplementasian terhadap sistem EHR yang sudah berjalan tersebut, diharapkan agar RSUD Ratu Zalecha Martapura dapat mengetahui dan lebih memahami hambatan-hambatan maupun kelemahan dan keuntungan dari penggunaan sistem yang selama ini berjalan. Dari paparan tersebut, maka fokus peneliti lebih tertarik mendalami bagaimana Implementasi EHR pada Poli Rawat Jalan di RSUD Ratu Zalecha Martapura.

\section{Metode}

Penelitian ini merupakan penelitian kualitatif. Subjek dalam penelitian adalah kepala instalasi rekam medis, petugas IT, dokter dan perawat. Pengumpulan data Teknik pengumpulan data dengan menggunakan triangulasi data observasi, wawancara dan pengumpulan dokumen.
Analisis data dilakukan melalui 3 tahap, yaitu data reduction (reduksi data), data display (penyajian data), dan Conclusion Drawing / Verification.

\section{Hasil}

1. Sistem keamanan (security) pada sistem Electronic Health Record (EHR)

\section{a. Privacy atau confidentiality}

Hasil observasi didapat adanya privasi yang tertera dalam hak akses informasi saat login tenaga kesehatan memasukkan username dan password kedalam sistem rekam medis elektronik. bahwa

Hal ini didukung dari hasil wawancara

"Untuk di poliklinik di beri username dan password" (Informan 1, Petugas Poliknik)

Hasil wawancara menunjukkan bahwa setiap poliklinik mendapatkan username dan password saat login, sehingga kerahasiaan akses informasi terjamin dari pihak yang tidak memiliki wewenang.

Sesuai dengan wawancara kepada informan 2, yaitu

"Kita sendiri-sendirikan, jadi tidak semua user di rumah sakit ini dapat mengakses semuanya tapi kita batasi. Misalkan orang loket dia hanya bisa mendaftarkan saja, perawat di poli dia bisa melihat siapa saja pasiennya dan riwayatnya apa saja, dan yang menginput obat itu dokternya selain itu tidak bisa. Jadi untuk menjamin data orangnya dibatasin sesuai dengan haknya dia" (Informan 2, Petugas IT).

Hasil wawancara kepada informan 2 menunjukkan bahwa user mempunyai hak akses pada sistem rekam medis elektronik itu tersendiri sesuai apa yang dikerjakan dan sesuai tanggung jawab masing-masing user, mereka tidak dapat mengakses diluar apa yang dikerjakan.

Untuk kebijakan rumah sakit sendiri terdapat didalam wawancara kepada informan 2, yaitu :

"Tidak tertulis dirumah sakit, tapi kami sendiri yang menjaga kerahasiaannya." (Informan 2, Petugas IT)

Hasil wawancara kepada informan 2 yang memberitahukan bahwa rumah sakit sendiri belum mempunyai kebijakan atau aturan untuk menjaga kerahasiaan 
informasi data, namun petugas bagian IT sangat berusaha untuk menjaga dari orangorang yang tidak memiliki ijin hak akses informasi.

Dari hasil wawancara diatas dapat disimpulkan bahwa setiap user mendapatkan username dan password sehingga user tidak dapat mengakses yang bukan wewenang mereka, dan untuk menjaga kerahasiaannya bagian IT yang menjaga dari orang-orang yang tidak di ijinkan dan berkepentingan.

\section{b. Integrity}

Hasil observasi didapat dalam aplikasi sistem rekam medis elektronik standar perubahan atau pembetulan data di poliklinik rawat jalan dapat langsung di ubah atau diperbaiki.

Hal tersebut sesuai dengan wawancara terhadap informan A yaitu :

"Tidak ada, Standar prosedur operasional (SPO)nya belum dibuat tentang pembetulan jadi langsung bisa di ubah untuk sementara ini. lya, sesuai dengan apa yang dikerjakan. Poli memang belum ada SPO tetapi memang harus ada. Karna implementasi baru awal tahun dilakukan jadi belum semua poli yang menerapkan." (Informan 3, Kepala Instalasi Rekam Medis)

Hasil wawancara didapat bahwa RSUD belum memiliki SPO tentang perubahan data atau informasi pasien sehingga petugas poliklinik ataupun dokter dapat langsung mengubah data tersebut. Tetapi seharusnya RSUD Ratu Zalecha Martapura memiliki aturan/standar SPO tentang perubahan data.

Untuk perubahan bersifat besar, peneliti mendapatkan hasil wawancara kepada informan 2, yaitu :

"Itu kita lihat dulu dampaknya kalau merembet kemana-mana kita, misalkan di kasir pasien ini tindakannya ada yang kurang boleh ga kita tambahkan, jadi tanyakan kekasir dulu kali aja uangnya sudah di transfer ke bank kalau belum bisa kita tambahkan langsung. Itu perubahan kecil atau perubahan besar, kalau perubahan besar kami yang merubah tapi sepengetahuan dari pihak yang terkait."( Informan 2 Petugas IT)

Hasil wawancara kepada informan 2 didapatkan bahwa untuk perubahan yang bersifat besar, perubahan atau pembetulan data tersebut akan dilakukan bagian IT dengan sepengetahuan pihak yang terkait. Karena data tersebut bisa berpengaruh kepada bagian lain jika dilakukan oleh petugas poliklinik maupun dokter.

Dari hasil wawancara diatas dapat disimpulkan bahwa Standar prosedur operasional (SPO) tentang perubahan data masih belum dimiliki rumah sakit dan untuk petugas dapat langsung mengubah data pasien jika terdapat kesalahan tetapi untuk perubahan yang bersifat besar harus bagian IT yang mengubah dengan mendapatkan persetujuan dari semua pihak yang bersangkutan.

\section{c. Authentication}

Hasil observasi di poliklinik rawat jalan didalam rekam medis elektronik nama dan waktu untuk petugas kesehatan sudah secara otomatis ada didalam billing disaat pengisian diagnosa, tindakan, hanya saja untuk tanda tangan masih belum ada.

Hal tersebut sesuai dengan wawancara kepada informan 4 yaitu:

"Nama ada, tanggal ada, untuk jam dan tanda tangan tidak ada." (informan 4, Dokter Spesialis)

Hasil wawancara didapat bahwa nama dan tanggal sudah tersedia disaat kita mengisi diagnosa, tindakan ataupun resep obat, sehingga tidak mempersulit petugas untuk mengisinya. Namun untuk waktu dan tanda tangan petugas poliklik ataupun dokter harus mencetak riwayat pasien dan menggunakan tanda tangan basah.

\section{d. Availability}

Dari hasil observasi dipoliklinik rawat jalan RSUD Ratu Zalecha Martapura ketersediaan data saat pasien berobat mudah didapatkan/dicari. Hal tersebut juga sesuai dengan wawancara kepada informan 3, yaitu :

"lya sudah otomatis data tinggal ambil, kuncinya dari input awal misalkan data kunjungan hari ini nanti siang dprint langsung bisa. (Infoman 3, Kepala Instalasi Rekam Medis)

Hasil wawancara didapatkan bahwa ketersediaan data saat pencarian atau mereview informasi pasien didapatkan dengan mudah dan cepat sesuai dengan kebutuhan dan keperluan. Sehingga data 
yang dikerjakan hari ini, langsung bisa diprint saat poliklinik tutup.

Hal ini juga sesuai dengan hasil wawancara kepada informan 2, yaitu :

"Jadi tergantung kebutuhan data, ada data yang mudah dapat dicari dengan cepat." (Informan 2 Petugas IT)

Hasil wawancara dikatakan bahwa setiap kebutuhan data bisa langsung dicari dengan cepat namun tergantung data seperti apa yang dibutuhkan.

Dari hasil wawancara diatas dapat disimpulkan bahwa ketersediaan data pada rumah sakit mudah di dapatkan sesuai dengan data yang diperlukan dan saat pencarian informasi datalangsung dapat ditemukan dengan cepat.

\section{e. Access control}

Hasil wawancara kepada informan 3 mengenai aturan mengakses rekam medis elektronik, yaitu :

"Belum ada, tapi sudah di draf blum di sahkan" (informan 3, Kepala Instalasi Rekam Medis)

Hasil wawancara didapatkan bahwa belum ada aturan secara resmi yang menerapkan siapa saja yang dapat mengakses rekam medis elektronik tersebut,tetapi sudah terdapat draf-draf yang berhak dan berwenang dalam hak akses rekam medis elektronik namun belum disahkan secara resmi.

\section{f. Non-repudiation}

Berdasarkan hasil wawancara kepada informan 2, yaitu :

"Setiap ada input data di rekam medis elektronik kami tulis di log file jadi ketahuan yang input siapa yang menghapus siapa. lya ketahuan siapa yang merubah"(informan 2, Petugas IT)

Hasil wawancara didapatkan bahwa tenaga kesehatan yang melakukan transaksi atau perubahan terhadap suatu informasi data pasien pada rekam medis elektronikakan terlihat dan terlacak hal tersebut masuk langsung pada bagian IT rumah sakit kedalam log file.

\section{Dukungan klinis (clinical support) pada sistem Electronic Health Record (EHR)}

Berdasarkan hasil observasi yang dilakukan fasilitas pendukung pengoperasian sistem rekam medis elektronik sudah memadai mungkin hanya terkadang masalah padamnya listrik. Selain itu, sesuai dengan hasil wawancara kepada informan 2 fasilitas pendukung yang mempengaruhi dalam penerapan sistem rekam medis elektronik yaitu :

"Pertama itu jaringan harus kuat, server juga harus kuat, karena yang akses banyak banget, dan perlu diawasi itu di jam jam tertentu traffic data tiba-tiba tinggi biasanya siang, perangkat komputer jangan jadul-jadul." (informan 2, Petugas IT)

Berdasarkan hasil wawancara didapat bahwa fasilitas yang paling mendukung adalah jaringannya harus kuat dalam pengimplementasian rekam medis elektronik karena yang mengakses aplikasi tidak hanya lingkaran kecil tetapi lingkaran besar dalam rumah sakit tersebut (banyak orang) sehingga jaringan, server, dan perangkat komputer yang terperbaharui harus kuat dan terbaru. Serta lebih memerhatikan pada jam-jam tertentu yang dimana hampir semua meaplikasikan/memakai rekam medis elektronik.

Berdasarkan hasil observasi yang dilakukan penginputan data pada sistem rekam medis elektronik perawat dan dokter sudah mengisi sendiri diagnosa, tindakan serta membuat resep obat sendiri namun masih ada beberapa dokter atau perawat yang medelegasikan tugas tersebut untuk di isi oleh admin ruangan, dengan memiliki alasan usia yang sudah terlalu tua sehingga akan memperlambat pelayanan.

Berdasarkan hasil observasi yang dilakukan waktu pelayanan dan perawatan terhadap pasien lebih efisien dan cepat. Dan setelah dilakukan wawancara kepada informan 1, yaitu :

"Waktu pelayanan menjadi efisien dan meningkatnya pelayanan perawatan pasien karena lebih maju dan pasien tidak perlu membawa kertas ke apotik." Informan 1 (Petugas Poliklinik)

Hasil wawancara didapatkan bahwa waktu pelayanan menjadi lebih efisien dan meningkatnya pelayanan perawatan pasien sesuai dengan hasil observasi yang dilakukan oleh peneliti. Hal tersebut mempermudah dan menguntungkan bagi tenaga kesehatan dan pasien itu sendiri. 
Adanya penghambat yang didapatkan peneliti sesuai dengan wawancara kepada informan 4 yaitu :

"2 kali kerja untuk berkas dan resep, tidak semua yang menggunakan aplikasi sama awal-awal tampilannya bingung." (Informan 4, Dokter spesialis)

Hasil wawancara didapatkan bahwa informan mengeluhkan karena mereka menjadi 2 kali kerja, menulis diagnosa menggunakan kertas dan menggunakan komputer karena masih ada beberapa poliklinik yang masih belum menerapkan sistem rekam medis elektronik sehingga saat rujukan dari poliklinik lain tetap menggunakan kertas dan untuk resep obat juga masih beberapa yang menggunakan kertas karena poliklinik sebagian sudah menerapkan sebagian lainnya masih tetap menggunakan berkas kertas. Serta tenaga kesehatan yang masih bingung dengan aplikasi disaat awal penerapan rekam medis elektronik sehingga sebagian tenaga kesehatan masih menulis dengan berkas rekam medis kertas.

Dari hasil wawancara dapat disimpulkan bahwa fasilitas pendukung yang ada di rumah sakit jaringan, server, dan perangkat komputer yang terperbaharui harus kuat dan terbaru. Untuk waktu lebih efisien dan meningkatnya pelayanan perawatan pasien sehingga mempermudah pasien. Didalam pengimplementasian terdapat penghambat yaitu untuk poliklinik yang sudah menerapkan rekam medis elektronik para dokter ataupun petugas poliklinik/perawat mengeluhkan karena menjadi 2 kali kerja saat penulisan diagnosa, tindakan, obat ataupun rujukan masih menggunakan kertas karena beberapa poliklinik yang belum menerapkan aplikasi.

\section{Laporan (report) pada sistem Electronic Health Record (EHR)}

Didalam aplikasi sistem Electronic Health Record (EHR) di RSUD Ratu Zalecha Martapura terdapat 2 (dua) menu sistem yang digunakan di rawat jalan yaitu tindakan rawat jalan dan kasir rawat jalan. Sehingga dari tindakan rawat jalan dan kasir rawat jalan dapat di olah langsung pelaporan rumah sakit.

Didalam sistem tindakan rawat jalan ada beberapa perawatan yang akan di input di antaranya penanganan dokter, penanganan perawat, penanganan dokter dan perawat, pemeriksaan, catatan resep obat, ringkasaan riwayat pemeriksaan (Format bisa dilihat di lampiran 8 s.d 13). Sedangkan didalam sistem kasir rawat jalan adalah laporan pendapatan rawat jalan dan laporan jasa pelayanan. Dan pelaporan yang dihasilkan didalam aplikasi rekam medis elektronik adalah laporan 10 besar penyakit rawat jalan, laporan kunjungan pasien rawat jalan, laporan sensus harian rawat jalan, $R L$ 1, $R L$ 2, $R L$ 3, $R L 4$ dan $R L$ 5.

Pada saat wawancara kepada informan 3, yaitu:

"Untuk pelaporan semua sudah tersedia didalam rekam medis elektronik jadi orang rekam medis tinggal ambil di aplikasi."'Sama seperti sebelumnya, laporan nya dari pusat bedanya dulu dengan hitungan manual sekarang tinggal klik sudah bisa tersedia pelaporannya." (Informan 3, Kepala Instalasi Rekam Medis)

Berdasarkan hasil wawancara dapat disimpulkan bahwa pengolah dan penyajian data untuk pelaporan yang ada di RSUD Ratu Zalecha Martapura pada sistem rekam medis elektronik, untuk penyajian dan pengolahan data tidak dilakukan lagi secara manual semua pelaporan rekam medis elektronik dapat di ambil langsung dari sistem dan sistem langsung mengolah.

\section{Pembahasan}

\section{Sistem Keamanan (security) a. Privacy atau Confidentiality}

Berdasarkan hasil penelitian didapat RSUD Ratu Zalecha sudah baik dalam menjaga kerahasiaan serta untuk setiap tenaga kesehatan diberikan username dan password hanya saja untuk perawat/petugas poliklinik diberikan satu username dan password untuk setiap poliklinik. Setiap user tidak dapat mengakses yang bukan wewenang mereka, dan untuk menjaga kerahasiaannya bagian IT yang menjaga dari orang-orang yang tidak di ijinkan dan berkepentingan.

Undang-undang Praktik Kedokteran Nomor 29 tahun 2004 bahwa untuk menjaga informasi dari pihak-pihak yang tidak memiliki hak untuk mengakses informasi tersebut.Data rekam medis yang berisi riwayat kesehatan pasien yang 
bersifat rahasia harus dapat dijaga kerahasiaanya, karena infomasi tersebut merupakan milik pasien.Sedangkan dokumennya merupakan milik dokter, dokter gigi, atau sarana pelayanan kesehatan (5).

Rekam medis elektronik di RSUD Ratu Zalecha Martapura sendiri belum mempunyai kebijakan rumah sakit atau aturan untuk menjaga kerahasiaan informasi data, namun petugas bagian IT sangat berusaha untuk menjaga dari orangorang yang tidak memiliki ijin hak akses. IT juga membatasi setiap penggunaan sesuai dengan kewenangan mereka kerjakan dan tanggung jawabkan masing-masing.

\section{b. Integrity}

Hasil penelitian menunjukkan bahwa standar perubahan atau pembetulan data dipoliklinik rawat jalan di RSUD Ratu Zalecha Martapura setiap tenaga kesehatan dapat mengubah secara langsung, namun untuk perubahan yang bersifat besar harus mengkonfirmasi kebagian IT dan bagian IT yang akan melakukan perubahan dengan sepengetahuan semua pihak yang terlibat. Perubahan tersebut misalkan petugas poliklinik/perawat melakukan pengisian tindakan keperawatan, namun setelah pasien pulang tindakan tersebut ada yang kurang. Jadi untuk petugas poliklinik/perawat harus melaporkan pada bagian IT, sehingga bagian IT akan bertanya kepada bagian kasir apakah tindakan tersebut uangnya sudah di setorkan ke bank atau belum. Jika belum maka bagian IT akan mengubah / menambahkan tindakan tersebut dengan sepengetahuan semua pihak yang terlibat. Integrity berkaitan mengenai perubahan informasi. Seperti yang tertuang Peraturan Menteri Kesehatan Republik Indonesia No. 269/ Menkes/ Per/ III/ 2008 tentang Rekam Medis pembetulan sebagaimana dimaksud pada ayat (5) hanya dapat dilakukan dengan cara pencoretan tanpa menghilangkan catatan yang dibetulkan dan dibubuhi paraf dokter, dokter gigi atau tenaga kesehatan tertentu yang bersangkutan."

Pencoretan tentu saja tidak bisa dilakukan dalam rekam kesehatan elektronik.Oleh karena itu diperlukan pengamanan atau proteksi yang lebih yaitu tidak begitu saja menghapus data yang tersimpan dalam rekam kesehatan elektronik tersebut dan segala perubahannya dapat diketahui.

Untuk perubahan data didalam rekam medis elektronik di RSUD Ratu Zalecha Martapura belum memiliki SPO, akan sebaiknya SPO tersebut dibuat sehingga terdapatnya aturan standar perubaan/ pembetulan data.

Perubahan/ pembetulan data yang dilakukan di rekam medis elektronik akan terlacak dan terinformasi kepada bagian IT. Untuk perubahan data catattan dapat langsung diubah didalam aplikasi, namun untuk catatan sebelum dilakukannya perubahan tersimpan didalam rekam medis elektronik, yang hanya bagian IT dapat melihat catatannya.

\section{c. Authentication}

Hasil penelitian menunjukkan bahwa akses terhadap informasi. tidak semua tenaga kesehatan dapat memasukkan data atau melakukan perubahan data.Setiap tenaga kesehatan mempunyai kapasitanya masing-masing, oleh karena itu perlu adanya pembatasan akses.Setiap perubahan harus ada pertanggungjawaban.

Undang-undang Praktik Kedokteran Nomor. 29 tahun 2004 Pasal 46 menyebutkan bahwa "setiap catatan rekam medis harus dibubuhi nama, waktu, dan tanda tangan petugas yang memberikan pelayanan atau tindakan". Dan pada pasal yang sama ayat (3) menyebutkan "apabila dalam pencatatan rekam medik menggunakan teknologi informasi elektronik, kewajiban membubuhi tanda tangan dapat diganti dengan menggunakan nomor identitas pribadi (PIN) (5)

Pada saat autentifikasi didalam rekam medis elektronik di RSUD Ratu Zalecha Martapura, tidak semua tenaga kesehatan yang dapat mengakses dan mengisi rekam medis elektronik hal tersebut sudah dibatasi oleh pihak IT sehingga tenaga kesehatan yang tidak memiliki username dan password tidak dapat melogin aplikasi. Di saat pengisian rekam medis elektronik petugas kesehatan tidak perlu mengisi nama, waktu dan tanda tangan karena nama dan waktu untuk petugas kesehatan sudah secara otomatis ada didalam billing sistem disaat pengisian diagnosa, tindakan, 
dan pengisian lainnya hanya saja untuk tanda tangan masih menggunakan tanda tangan basah. Sehingga data tersebut harus diprint terlebih dahulu. Data nama dan waktu tersebut sudah secara otomatis ada disaat tenaga kesehatan melogin user mereka. Untuk menjaga keabsahan disaaat melakukan pengisian rekam medis elektronik, tenaga kesehatan diminta untuk mengisi kode dokter (untuk dokter) dan NIP (untuk perawat/petugas poliklinik).

Undang-undang ITE Nomor 11 Tahun 2008 pasal 16 menyatakan bahwa ada Rekam Kesehatan Elektronik juga wajib diberi tanda tangan untuk pertanggungjawaban yaitu: Tanda tangan elektronik memiliki kekuatan hukum akibat hukum yang sah selama memenuhi persyaratan sebagai berikut : 1) Data pembuatan tanda tangan elektronik terkait hanya kepada penanda tangan. 2) Data pembuatan tanda tangan elektronik pada saat proses penandatanganan elektronik hanya berada dalam kausa penanda tangan. 3) Segala perubahan terhadap tanda tangan elektronik yang terjadi setelah waktu penandatanganan dapat diketahui. 4) Segala perubahan terhadap informasi elektronik yang terkait tanda tangan elektronik tersebut setelah waktu penandatanganan dapat diketahui. 5) Terdapat cara tertentu yang dipakai untuk mengidentifikasi

siapa penandatanganannya. 6) Terdapat cara tertentu untuk menunjukkan bahwa penanda tangan telah memberikan persetujuan terhadap informasi elektronik terkait (6)

\section{d. Availability}

Hasil penelitian menunjukkan bahwa ketersediaan data rekam medis elektronik bisa di akses secara cepat didalam sistem sehingga mempermudah tenaga kesehatan mencari data yang dibutuhkan atau data yang baru saja di input.

Untuk rekam kesehatan ekektronik juga harus mempunyai sifat ketersediaan yaitu: Sepanjang tidak ditentukan lain oleh undang-undang tersendiri, setiap Penyelengaraan Sistem Elektronik wajib mengoperasikan sistem elektronik yang memenuhi persyaratan minimum sebagai berikut : 1) Dapat menampilkan kembali Informasi elektronik dan/atau dokumen elektronik secara utuh sesuai dengan masa retensi yang diterapkan dalam peraturan perundang-undangan. 2) Dapat melindungi ketersediaan, keutuhan. Keautentikan, kerahasiaan dan keteraksesan informasi elektronk dalam Penyelengaraan Sistem Elektronik tersebut. 3) Dapat beroperasi sesuai dengan prosedur atau petunjuk dalam Penyelengaraan Sistem Elektronik tersebut. 4) Dilengkapi dangan prosedur atau petunjuk yang diumumkan dengan bahasa, informasi, atau simbol yang dapat dipahami oleh pihak yang bersangkutan dengan Penyelengaraan Sistem Elektronik tersebut. 5) Memiliki mekanisme yang berkelanjutan untuk menjaga kebaruan, kejelasan, dan kebertanggung jawaban prosedur atau petunjuk.

\section{e. Access Control}

Hasil penelitian menunjukkan bahwa bahwa belum ada aturan secara resmi yang menerapkan siapa saja yang dapat mengakses rekam medis elektronik tersebut,tetapi sudah terdapat draf-draf yang berhak dan berwenang dalam hak akses rekam medis elektronik namun belum disahkan secara resmi.

Access control adalah aspek yang menekankan pada cara pengaturan akses terhadap informasi. access control dapat mengatur siapa-siapa saja yang berhak untuk mengakses infomasi atau siapa-siapa saja yang tidak berhak mengakses informasi.

\section{f. Non-Repudiation}

Aspek ini erat kaitannya dengan suatu transaksi atau perubahan informasi. Aspek ini mencegah agar seseorang tidak dapat menyangkal telah melakukan transaksi atau perubahan terhadap suatu informasi.Sehingga petugas tenaga kesehatan di RSUD Ratu Zalecha Martapura yang melakukan transaksi atau perubahan terhadap suatu informasi data akan terlihat dan terlacak langsung pada bagian IT rumah sakit. Setiap ada yang menginput ataupun menghapus data informasi kedalam rekam medis elekteronik akan langsung terdapat pemberitahuan di log file pada bagian IT. Dalam PORMIKI disebutkan bahwa Non-repudiation atau tidak ada sanggahan adalah log perubahan data yang mencatat kapan waktu dilakukan 
perubahan, alamat komputer (dimana dilakukan perubahan), data apa yang diubah dan siapa yang melakukan perubahan. Sehingga log dari perubahan bisa terlihat dan terekam secara sistem.

Penelitian oleh Nuryati (2015) bahwa aspek control/security (kontrol/keamanan) sistem EHR (Electronic Health Record) sudah berjalan belum dapat menjaga privasi pasien karena dapat diakses oleh siapapun. Privasi sistem EHR masih kurang karena masing-masing staf medis dapat melihat EHR semua orang yang dikehendaki meskipun bukan pasien yang dikelola. Selain itu, legalitas system EHR dirasa pengguna sistem EHR kurang terpenuhi. Responden 74 mengatakan bahwa lembar informed consent belum terdapat dalam sistem EHR, sehingga mungkin dapat discan dan dijadikan satu pada sistem EHR (7).

Hasil penelitian oleh Darwito (2016) bahwa Algoritma ini diimplementasikan untuk mengamankan informasi rekam medis pasien pada sistem sharing data electronic health record (EHR). Algoritma ini menjadi sangat penting sekali karena informasi mengenai rekam medis pasien digunakan untuk memberikan rujukan kepada dokter dan ke rumah sakit yang berbeda melalui sistem jaringan cloud (8)

Sistem EHR perlu diperhatikan dalam penggunaannya terkait persetujuan (concern) pasien dan tenaga kesehatan, persyaratan khusus tertentu dari spesialisasi medis, serta segi keamanan dan persetujuan kerahasiaan yang harus dipenuhi (9).

\section{Dukungan Klinis (Clinical Support)}

Komponen fungsional EHR meliputi data pasien terintegrasi, dukungan keputasan klinis, pemasukan perintah klinikus, akses terhadap sumber pengetahuan dan dukungan komunikasi terpadu (10).

Dukungan klinis yaitu pengetahuan pendukung pengambilan keputusan yang tidak terlepas dari dukungan beberapa faktor, seperti faktor sumber daya, kelengkapan diagnosa, dan fasilitas. Secara umum, sistem dukungan keputusan klinis (Clinical Decision Support) memerlukan informasi yang terstruktur karena untuk tujuan pelaporan untuk peningkatan kualitas pelayanan (11).

$$
\text { Banyaknya }
$$

faktor yang

mempengaruhi dalam sistem penerapan rekam medis elektronik di RSUD Ratu Zalecha Martapura salah satunya faktor fasilitas yang mendukung penerapan ini, pada fasilitas yang ada dirumah sakit sebelum penerapan setiap poliklinik sudah mendapatkan komputer namun yang masih menjadi kendala yaitu terkadang padamnya listrik hal tersebut bisa menghambat pengoperasian rekam medis elektronik. Fasilitas pada rekam medis elektronik memberi kemudahan kepada petugas dalam setiap pelaksanaan

Penginputan data pada sistem rekam medis elektronik perawat dan dokter sudah mengisi sendiri diagnosa, tindakan serta membuat resep obat sendiri namun masih ada beberapa dokter atau perawat yang medelegasikan tugas tersebut untuk di isi oleh admin ruangan, dengan memiliki alasan usia yang sudah terlalu tua sehingga akan memperlambat pelayanan. Namun waktu pelayanan dan perawatan terhadap pasien lebih efisien dan cepat sehingga mempermudah pasien dan petugas kesehatan karena mudahnya mencari riwayat atau mereview rekam medis terdahulu

\section{Laporan (report)}

Berdasarkan penelitian ini laporan yang ada di RSUD Ratu Zalecha Martapura berjalan sesuai dengan periodik yang telah ditetapkan pemerintah. Rumah sakit belum memiliki SPO pelaporan rekam medis elektronik. Untuk alur pelaporan sendiri masih sama seperti pelaporan berbasis kertas hanya saja untuk penyajian dan pengolahan data sudah bisa diambil langsung dalam aplikasi.

Sistem Electronic Health Record (EHR) di RSUD Ratu Zalecha Martapura terdapat 2 (dua) menu sistem yang digunakan di rawat jalan yaitu tindakan rawat jalan dan kasir rawat jalan. Didalam sistem tindakan rawat jalan ada beberapa perawatan yang akan di input di antaranya penanganan dokter, penanganan perawat, penanganan dokter dan perawat, pemeriksaan, catatan resep obat, ringkasaan riwayat pemeriksaan. 
Sedangkan didalam sistem kasir rawat jalan adalah laporan pendapatan rawat jalan dan laporan jasa pelayanan. Didalam sistem tersebut pelaporan sudah diolah dan disajikan langsung, laporan yang dihasilkan yaitu laporan 10 besar penyakit rawat jalan, laporan kunjungan pasien rawat jalan, laporan sensus harian rawat jalan, $R L 1, R L$ 2, RL 3, RL 4 dan RL 5.

Pelaporan rumah sakit adalah suatu kegiatan pelayanan kesehatan di rumah sakit yang mempunyai tugas melakukan pengumpulan data, mengolah data, dan menyajikan data menjadi suatu informasi. Pelaporan SIRS terdiri dari 5 (lima) Rekapitulasi Laporan ( $R L)(8)$ ditetapkan oleh Direktur Jendral Bina Upaya Kesehatan, diantaranya : 1) RL 1 berisikan data rumah sakit yang dilaporkan setiap waktu apabila terdapat perubahan data dasar dari rumah sakit sehingga data ini dapat dikatakan data yang bersifat terbarukan setiap saat (updated). 2) RL 2 berisikan Data Ketenagaan yang dilaporkan periodik setiap tahun. 3) RL 3 berisikan Data Kegiatan Pelayanan Rumah Sakit yang dilaporkan periodik setiap tahun dan dibuat setiap triwulan oleh rumah sakit berdasarkan pencatatan harian yang dikomplikasikan setiap bulan. 4) $\mathrm{RL} 4$ berisikan data morbiditas atau mortalitas pasien yang dilaporkan periodik setiap tahun. 5) RL 5 merupakan data bulanan yang dilaporkan secara periodik setiap bulan, berisikan data kunjungan dan data 10 (sepuluh) besar penyakit.

\section{Kesimpulan}

1. Untuk dapat mengakses EHR user harus menggunakan username dan password. Username dan password dibuat sesuai batasan dan kewenangan masing-masing user. Sehingga user dapat melakukan perubahan data secara langsung saat pengisian rekam medis elektronik.

2. Dukungan klinis (clinical support) pada sistem Electronic Health Record (EHR) di RSUD Ratu Zalecha Martapura sudah baik, dokter dan perawat mengisi diagnosa sendiri ke dalam aplikasi EHR, waktu pelayanan lebih efisien dan lebih cepat sehingga meningkatkan pelayanan pasien.
3. Laporan yang dihasilkan sistem EHR yaitu laporan 10 besar penyakit rawat jalan, laporan kunjungan pasien rawat jalan, laporan sensus harian rawat jalan, $R L$ 1, RL 2, RL 3, RL 4 dan RL 5.

\section{Daftar Pustaka}

1. Undang-Undang Republik Indonesia Nomor 44 Tahun 2009 Tentang Rumah Sakit. Jakarta: Biro Peraturan Perundang-undangan Bidang Politik dan Kesejahteraan Rakyat; 2009

2. Wager, K. A., Lee, F. W., Glaser, J. P., Health care information systems: a practical approach for health care management. John Wiley \& Sons; Mar $27 ; 2017$.

3. Peterson L. T., Ford E. W., Eberhardt J., Huerta T. R., Menachemi N. Assessing differences between physicians' realized and anticipated gains from electronic health record adoption. Journal of Medical Systems. 2011; 35: 151161. doi:10.1007/s10916-009-9352-z.

4. AHIMA. "Data Quality Management Model (Updated). "Journal of AHIMA 83 (7) p. 62-67; 2012. Available from: http://library.ahima.org. [Cited 12 March 2018].

5. Undang-undang Praktik Kedokteran Nomor 29 tahun 2004

6. DPR RI. Undang-undang ITE Nomor 11 Tahun 2008

7. Nuryati; Nurzara anggar Widayant. Evaluasi Implementasi Sistem ELECTRONIC HEALTH RECORD (EHR) Di Rumah Sakit Akademik Universitas Gadjah Mada Berdasarkan Metode Analisis Pieces. Jurnal Manajemen Informasi Kesehatan Indonesia. Vol.3, No.1, Maret 2015

8. Darwito. Implementasi Sistem Keamanan Sharing Electronic Health Record (EHR) Berbasis 3DES. Prosiding SENTIA 2016 - Politeknik Negeri Malang. Volume $8 ; 2016$

9. Beard, L., Schein, R., Morra, D., Wilson, K., Keelan, J. "The Challenges in Making Electronic Health Records Accessible to Patients". Journal of the American Medical Informatics Association 19 (1) p.116-120; 2001

10. Harlan, Johan. Informatika Kesehatan. Jakarta : Gunadarma; 2006 
11. Appari A., Johnson M. E., Anthony D. L. Meaningful use of electronic health record systems and process quality of care: Evidence from a panel data analysis of U.S. acute-care hospitals. Health Services Research. 2013;48:3 